Atmos. Chem. Phys., 17, 10583-10595, 2017

https://doi.org/10.5194/acp-17-10583-2017

(c) Author(s) 2017. This work is distributed under

the Creative Commons Attribution 3.0 License.

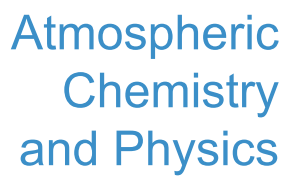

(c) (P)

\title{
Ice-nucleating particles in Canadian Arctic sea-surface microlayer and bulk seawater
}

\author{
Victoria E. Irish ${ }^{1}$, Pablo Elizondo ${ }^{1}$, Jessie Chen ${ }^{1}$, Cédric Chou ${ }^{1}$, Joannie Charette ${ }^{2}$, Martine Lizotte ${ }^{3}$, \\ Luis A. Ladino ${ }^{4, a}$, Theodore W. Wilson ${ }^{5}$, Michel Gosselin ${ }^{2}$, Benjamin J. Murray ${ }^{5}$, Elena Polishchuk ${ }^{1}$, \\ Jonathan P. D. Abbatt ${ }^{4}$, Lisa A. Miller ${ }^{6}$, and Allan K. Bertram ${ }^{1}$ \\ ${ }^{1}$ Department of Chemistry, University of British Columbia, 2036 Main Mall, Vancouver, BC V6T 1Z1, Canada \\ ${ }^{2}$ Institut des sciences de la mer de Rimouski, Université du Québec à Rimouski, 310 Allée des Ursulines, Rimouski, \\ Québec, QC G5L 3A1, Canada \\ ${ }^{3}$ Département de biologie, Québec-Océan, Université Laval, Québec, QC G1V 0A6, Canada \\ ${ }^{4}$ Department of Chemistry, University of Toronto, 80 St George Street, Toronto, Ontario, ON M5S 3H6, Canada \\ ${ }^{5}$ Institute for Climate and Atmospheric Science, School of Earth and Environment, University of Leeds, \\ Woodhouse Lane, Leeds, LS2 9JT, UK \\ ${ }^{6}$ Institute of Ocean Sciences, Fisheries and Oceans Canada, Sidney, BC V8L 4B2, Canada \\ ${ }^{a}$ now at: Centro de Ciencias de la Atmósfera, Universidad Nacional Autónoma de México, Ciudad Universitaria, \\ Mexico City, Mexico
}

Correspondence to: Allan Bertram (bertram@chem.ubc.ca)

Received: 26 April 2017 - Discussion started: 27 April 2017

Revised: 27 July 2017 - Accepted: 7 August 2017 - Published: 8 September 2017

\begin{abstract}
The sea-surface microlayer and bulk seawater can contain ice-nucleating particles (INPs) and these INPs can be emitted into the atmosphere. Our current understanding of the properties, concentrations, and spatial and temporal distributions of INPs in the microlayer and bulk seawater is limited. In this study we investigate the concentrations and properties of INPs in microlayer and bulk seawater samples collected in the Canadian Arctic during the summer of 2014. INPs were ubiquitous in the microlayer and bulk seawater with freezing temperatures in the immersion mode as high as $-14^{\circ} \mathrm{C}$. A strong negative correlation $(R=-0.7, p=0.02)$ was observed between salinity and freezing temperatures (after correction for freezing depression by the salts). One possible explanation is that INPs were associated with melting sea ice. Heat and filtration treatments of the samples show that the INPs were likely heat-labile biological materials with sizes between 0.02 and $0.2 \mu \mathrm{m}$ in diameter, consistent with previous measurements off the coast of North America and near Greenland in the Arctic. The concentrations of INPs in the microlayer and bulk seawater were consistent with previous measurements at several other locations off the coast of North America. However, our average microlayer concentra-
\end{abstract}

tion was lower than previous observations made near Greenland in the Arctic. This difference could not be explained by chlorophyll $a$ concentrations derived from satellite measurements. In addition, previous studies found significant INP enrichment in the microlayer, relative to bulk seawater, which we did not observe in this study. While further studies are needed to understand these differences, we confirm that there is a source of INP in the microlayer and bulk seawater in the Canadian Arctic that may be important for atmospheric INP concentrations.

\section{Introduction}

Ice can form in clouds by homogeneous or heterogeneous ice nucleation. Homogeneous ice nucleation refers to ice nucleation in the absence of a foreign substrate, while heterogeneous ice nucleation refers to ice nucleation initiated by a foreign substrate or an ice-nucleating particle (INP). Homogeneous ice nucleation becomes increasingly important below approximately $-33^{\circ} \mathrm{C}$ for typical cloud sizes and atmospheric cooling rates (Herbert et al., 2015; Koop and Mur- 
ray, 2016), but INPs can trigger ice formation in clouds at higher temperatures. Therefore, INPs in the atmosphere can affect Earth's climate and the hydrological cycle by altering the microphysics, radiative properties, and lifetime of clouds (DeMott et al., 2010; Lohmann, 2002; Lohmann and Feichter, 2005; Tan et al., 2016).

Field and laboratory studies have shown that the seasurface microlayer and bulk seawater contain INPs and that these INPs can be emitted to the atmosphere by the bubblebursting mechanism (Alpert et al.,, 2011a, b; Blanchard, 1964; DeMott et al., 2015; Fahlgren et al., 2015; Fall and Schnell, 1985; Knopf and Forrester, 2011; Prather et al., 2013; Rosinski et al., 1988; Schnell, 1977; Schnell and Vali, 1975, 1976; Vali et al., 1976; Wang et al., 2015; Wilson et al., 2015). The sea-surface microlayer (herein referred to as the microlayer) is the interface between the ocean and the atmosphere. The thickness of the microlayer is $<1 \mathrm{~mm}$ (Liss and Duce, 1997), and the physical and chemical properties of the microlayer are different from those of bulk seawater (Zhang et al., 2003). For example, the concentration of organic material is often enhanced in the microlayer compared to bulk seawater (Wurl et al., 2009).

Modelling studies have suggested that the ocean can be a dominant source of INPs in the atmosphere when dust concentrations are low (Burrows et al., 2013; Vergara-Temprado et al., 2017; Wilson et al., 2015). Modelling studies show that natural marine INPs may contribute to more ice formation in mixed-phase clouds, thereby reducing the magnitude of the total top-of-atmosphere anthropogenic aerosol forcing by as much as $0.3 \mathrm{~W} \mathrm{~m}^{-2}$ (Yun and Penner, 2013). Nevertheless, our current understanding of the properties, concentrations, and spatial and temporal distributions of INPs in the microlayer and bulk seawater, as well as their transfer to the atmosphere, remains limited, leading to uncertainties when predicting their impacts on climate and the hydrological cycle.

Prior to our work, five studies had examined INPs in bulk waters around North America and near Greenland (Fig. 1), but only one quantified INPs in the microlayer in the immersion mode (Wilson et al., 2015). The immersion mode refers to heterogeneous freezing caused by INPs immersed in liquid droplets, which is the mode most relevant for mixed-phase clouds in the atmosphere (Murray et al., 2012). Our work adds more measurements to the limited data on INPs in the microlayer and bulk seawater, contributing to a better understanding of how the properties and concentrations of INPs in the microlayer vary with location and time.

We investigated the concentrations and properties of INPs in the microlayer and bulk seawater samples in the immersion mode collected in the Canadian Arctic (Fig. 1) during the summer of 2014. The Arctic was chosen for these studies because (1) clouds in this region have been found to be especially sensitive to atmospheric concentrations of INPs (Harrington et al., 1999; Jiang et al., 2000), (2) there have not been previous studies of the freezing properties of the microlayer or bulk seawater in this region, and (3) as sea ice continues to decrease in the Arctic, the microlayer and bulk seawater may become more important sources of INPs in this region.

\section{Experimental}

\subsection{Sampling locations and collection methods}

All samples were collected during July and August 2014 from the eastern Canadian Arctic on-board the Canadian research icebreaker CCGS Amundsen as part of the Network on Climate and Aerosols: Addressing Key Uncertainties in Remote Canadian Environments (NETCARE) project. The locations of the eight stations sampled in this study are shown in Fig. 1 while Table 1 describes sampling times and specific geographic coordinates of these stations. Supplementary details, including notes and photographs taken at each station during sampling, are provided in Table S1.

The microlayer samples were collected using a glass plate sampler (Harvey and Burzell, 1972) from the upwind side of a small inflatable, rigid-hull boat, at least $500 \mathrm{~m}$ away from the CCGS Amundsen to avoid contamination. The glass plate was immersed vertically and withdrawn at a slow rate (between 3 to $5 \mathrm{~cm} \mathrm{~s}^{-1}$ ) and allowed to drain for less than $5 \mathrm{~s}$. The microlayer that adhered to the plate from each dip was scraped off from one side of the glass plate with a neoprene wiper blade into a $1 \mathrm{~L}$ high-density polyethylene (HDPE) Nalgene bottle. For each microlayer sample, approximately 500-1000 mL was collected, requiring 115-185 dips. Based on the amount of material collected, the number of dips and the area of the plate, the thickness of the layer collected ranged between 60 and $220 \mu \mathrm{m}$. Bulk seawater samples were collected at the same times and locations as the microlayer samples using a Niskin bottle deployed from the downwind side of the zodiac. Samples were collected at $0.5 \mathrm{~m}$ depth and transferred to $1 \mathrm{~L}$ HDPE Nalgene bottles. After collection, the Nalgene bottles containing both the microlayer and bulk samples were kept cool in an insulated container. Upon returning to the ship, the samples were homogenised by gently inverting them at least 10 times and then they were subsampled into smaller bottles for subsequent analyses.

The glass plate, neoprene wiper blade and all Nalgene bottles were cleaned with isopropanol and ultrapure water and rinsed with approximately $10 \mathrm{~mL}$ of the seawater sample before use. Isopropanol has been used in previous presterilisation protocols (Csuros, 1994). The Niskin bottle was not cleaned with isopropanol before sampling, but the inside of the bottle was rinsed with a large amount of seawater by lowering and leaving it in the seawater with the top and bottom lids open for about a minute before sending down the messenger to close the lids for sample collection. Sampling with the Niskin bottle and the handheld glass plate was done 


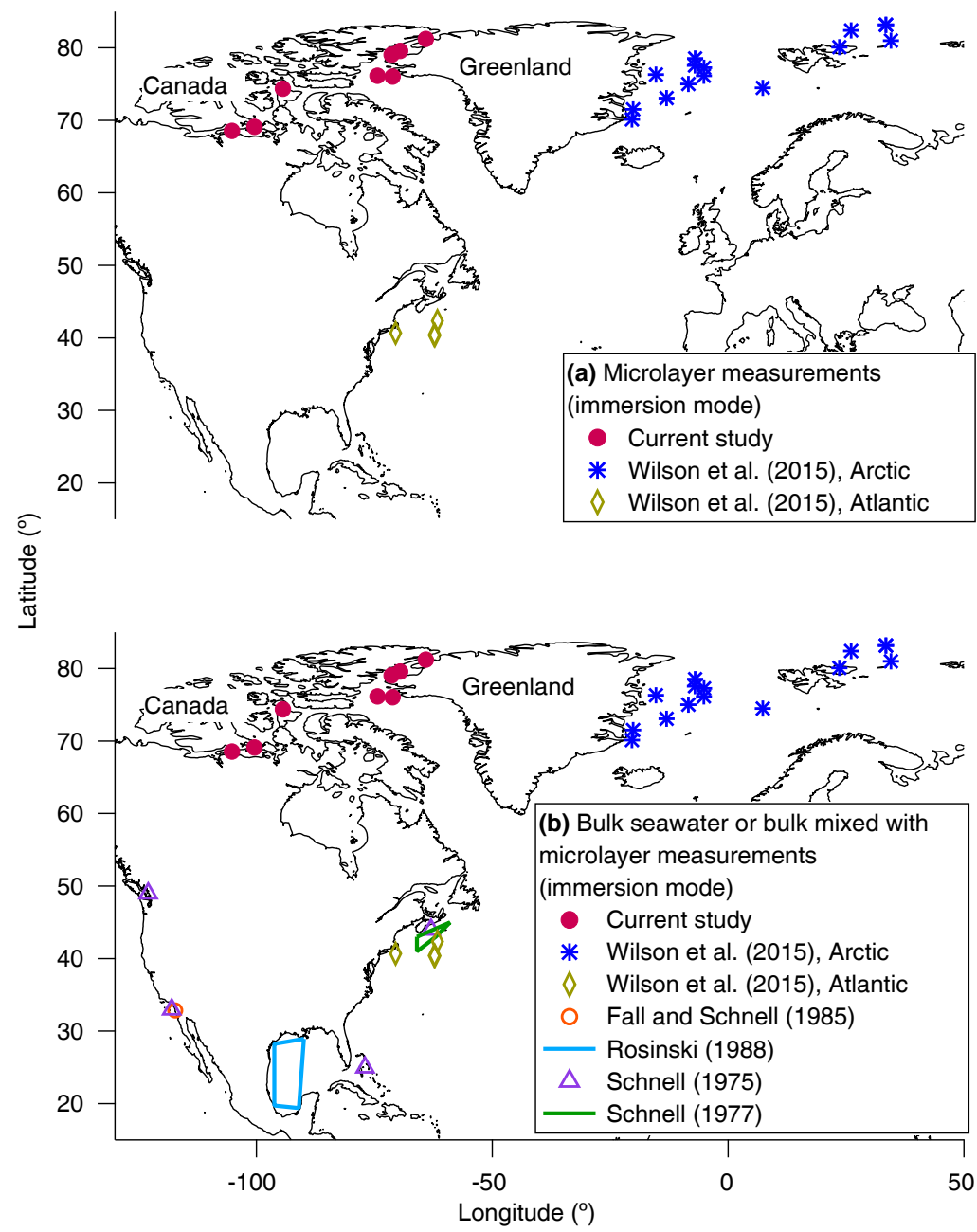

Figure 1. Panel (a) shows locations of current and previous studies of INPs (immersion mode) in the microlayer. Panel (b) shows locations of current and previous studies of INPs (immersion mode) in bulk seawater or mixtures of bulk seawater and the microlayer. Dates and coordinates for samples in the current study can be found in Table 1.

on opposite sides of the zodiac to minimise the effect of sampling with the Niskin bottle on the microlayer.

\subsection{Ice-nucleation properties of the samples}

\subsubsection{Droplet freezing technique and INP concentrations}

INP concentrations as a function of temperature were determined using the droplet freezing technique (DFT; Koop et al., 1998; Vali, 1971; Whale et al., 2015; Wilson et al., 2015). Subsamples of the microlayer and bulk seawater were stored in Nalgene bottles frozen at $-80^{\circ} \mathrm{C}$ for a maximum of 9 months before INP analysis. A previous study suggests that freezing seawater samples does not significantly change the freezing properties of the samples (Schnell and Vali, 1975). Each microlayer and bulk seawater sample was completely thawed and homogenised by inverting at least 10 times. Be- tween 15 to 20 droplets of the sample, with volumes of $0.6 \mu \mathrm{L}$ each, were deposited onto a hydrophobic glass slide (HR3-215; Hampton Research, Aliso Viejo, CA, USA) using a pipette. The slides were put into an airtight cell (Parsons et al., 2004) attached to a cold stage and analysed by the DFT as detailed in Wheeler et al. (2015). The droplets were cooled at a constant rate of $5^{\circ} \mathrm{Cmin}^{-1}$ from 0 to $-35^{\circ} \mathrm{C}$. Each experiment was repeated three times using three different slides. "Blanks" were determined by filtering the microlayer and bulk samples through a $0.02 \mu \mathrm{m}$ Anotop 25 filter. Ultrapure water (distilled water further purified with a Millipore system, $18.2 \mathrm{M} \Omega \mathrm{cm}$ at $25^{\circ} \mathrm{C}$ ) was also analysed for INPs using the DFT for comparison.

The concentration of INPs, [INP(T)], was determined from each freezing experiment by the following equation (Vali, 1971): 
$[\operatorname{INP}(T)]=-\ln \left(\frac{N_{\mathrm{u}}(T)}{N_{o}}\right) N_{o} \cdot \frac{1}{V}$,

in which $N_{\mathrm{u}}(T)$ is the number of unfrozen droplets at temperature $T, N_{o}$ is the total number of droplets used in the experiment and $V$ is the volume of all droplets in a single experiment. This equation accounts for the possibility of multiple INPs contained in a single droplet.

\subsubsection{Heating tests}

The freezing temperatures of the microlayer and bulk samples were also measured after they had been heated to $100^{\circ} \mathrm{C}$ (Christner et al., 2008; Schnell and Vali, 1975; Wilson et al., 2015). This temperature was chosen because some biological materials have been shown to lose their ice nucleation activity following heating to $95^{\circ} \mathrm{C}$ (Christner et al., 2008), possibly due to denaturation of the tertiary structure of ice nucleating proteins (Hill et al., 2016). Samples of microlayer and bulk seawater were put into polypropylene tubes, sealed with lids, and heated to $100^{\circ} \mathrm{C}$ in a heating block (Accublock, Labnet, S/N: D1200) for an hour, then cooled to room temperature for approximately $30 \mathrm{~min}$ before freezing measurements.

\subsubsection{The size of the INPs}

Following Wilson et al. (2015), the microlayer and bulk seawater samples were passed through filters with three different pore sizes (Whatman $10 \mu \mathrm{m}$ pore size PTFE membranes, Millex -HV $0.2 \mu \mathrm{m}$ pore size PTFE membranes, and Anotop $250.02 \mu \mathrm{m}$ pore size inorganic Anopore ${ }^{\mathrm{TM}}$ membranes). These filtered samples were subsequently used in the freezing measurements.

\subsubsection{Corrections for freezing temperature depression}

Since the microlayer and bulk seawater samples contained salts, the measured freezing temperatures were adjusted for the presence of the salts. Using measured salinities and the approach based on water activity (Koop and Zobrist, 2009), hypothetical heterogeneous freezing temperatures for salt-free conditions were obtained (salinity $=0 \mathrm{~g} \mathrm{~kg}^{-1}$ ). The freezing temperature correction was calculated using the median freezing temperature of each sample and then applied to the rest of the droplet freezing temperatures within that sample. For details see the Supplement, Sect. S1. The salinities of the microlayer and bulk seawater samples were measured within $10 \mathrm{~min}$ of sample collection using a hand-held salinity probe (Symphony; VWR, Radnor, PA, USA) which had been calibrated against discrete seawater samples analysed on a Guildline Autosal 8400B. The correction for the presence of salts based on the measured salinities ranged from 2.0 to $2.8^{\circ} \mathrm{C}$. Hypothetical heterogeneous freezing temperatures for salt-free conditions are more relevant for mixed-
Table 1. Sampling times and geographic coordinates for the eight stations investigated during July-August 2014 in the Canadian Arctic.

\begin{tabular}{|c|c|c|}
\hline Station number & $\begin{array}{l}\text { Sampling start } \\
\text { time (UTC)* }\end{array}$ & Location \\
\hline Station 2 & 23 Jul 2014 17:10 & $\begin{array}{l}74^{\circ} 36^{\prime} 935 \mathrm{~N} \\
94^{\circ} 43^{\prime} 663 \mathrm{~W}\end{array}$ \\
\hline Station 4 & $30 \mathrm{Jul} 2014$ 22:10 & $\begin{array}{l}76^{\circ} 19^{\prime} 882 \mathrm{~N} \\
071^{\circ} 10^{\prime} 329 \mathrm{~W}\end{array}$ \\
\hline Station 5 & $31 \mathrm{Jul} 2014$ 21:00 & $\begin{array}{l}76^{\circ} 16^{\prime} 568 \mathrm{~N} \\
074^{\circ} 36^{\prime} 063 \mathrm{~W}\end{array}$ \\
\hline Station 6 & 3 Aug 2014 12:20 & $\begin{array}{l}81^{\circ} 21^{\prime} 743 \mathrm{~N} \\
064^{\circ} 11^{\prime} 399 \mathrm{~W}\end{array}$ \\
\hline Station 7 & 4 Aug 2014 18:40 & $\begin{array}{l}79^{\circ} 58^{\prime} 672 \mathrm{~N} \\
069^{\circ} 56^{\prime} 051 \mathrm{~W}\end{array}$ \\
\hline Station 8 & 5 Aug 2014 19:20 & $\begin{array}{l}79^{\circ} 04^{\prime} 673 \mathrm{~N} \\
071^{\circ} 39^{\prime} 205 \mathrm{~W}\end{array}$ \\
\hline Station 9 & 11 Aug 2014 20:00 & $\begin{array}{l}69^{\circ} 10^{\prime} 009 \mathrm{~N} \\
100^{\circ} 44^{\prime} 018 \mathrm{~W}\end{array}$ \\
\hline Station 10 & 12 Aug 2014 18:50 & $\begin{array}{l}68^{\circ} 55^{\prime} 897 \mathrm{~N} \\
105^{\circ} 19^{\prime} 809 \mathrm{~W}\end{array}$ \\
\hline
\end{tabular}

* Sampling took 45-90 min to complete.

phase clouds, in which freezing typically occurs in dilute aqueous droplets with low salt concentrations (i.e. in which water activity tends toward unity). The water activity corrections do not consider non-colligative effects; however, noncolligative effects have not been observed in previous immersion freezing studies with sodium chloride solutions (Alpert et al., 2011a, b; Knopf et al., 2011; Zobrist et al., 2008) or seawater (Wilson et al., 2015).

\subsection{Phytoplankton and bacterial abundance}

Duplicate $5 \mathrm{~mL}$ subsamples were fixed with $20 \mu \mathrm{L}$ of $25 \%$ grade I glutaraldehyde $(0.1 \%$ final concentration; SigmaAldrich G5882) and kept frozen at $-80^{\circ} \mathrm{C}$ until analysis using flow cytometry, within 7 months of collection (Marie et al., 2005). Cyanobacteria were identified by orange fluorescence from phycoerythrin $(575 \pm 20 \mathrm{~nm})$. Heterotrophic bacteria samples were stained with SYBR Green I and measured at $525 \mathrm{~nm}$ to detect low and high nucleic acid content (Belzile et al., 2008). Archaea could not be discriminated from bacteria using this protocol; therefore, hereafter, we use the term bacteria to include both archaea and bacteria. Photosynthetic eukaryotes were identified by red fluorescence of chlorophyll $(675 \pm 10 \mathrm{~nm})$. In each subsample, microspheres ( 1 and $2 \mu \mathrm{m}$, Fluoresbrite plain YG, Polysciences) were added as an internal standard as described by Tremblay et al. (2009). Analyses were performed on an Epics Altra flow cytometer (Beckman Coulter), fitted with a $488 \mathrm{~nm}$ laser 


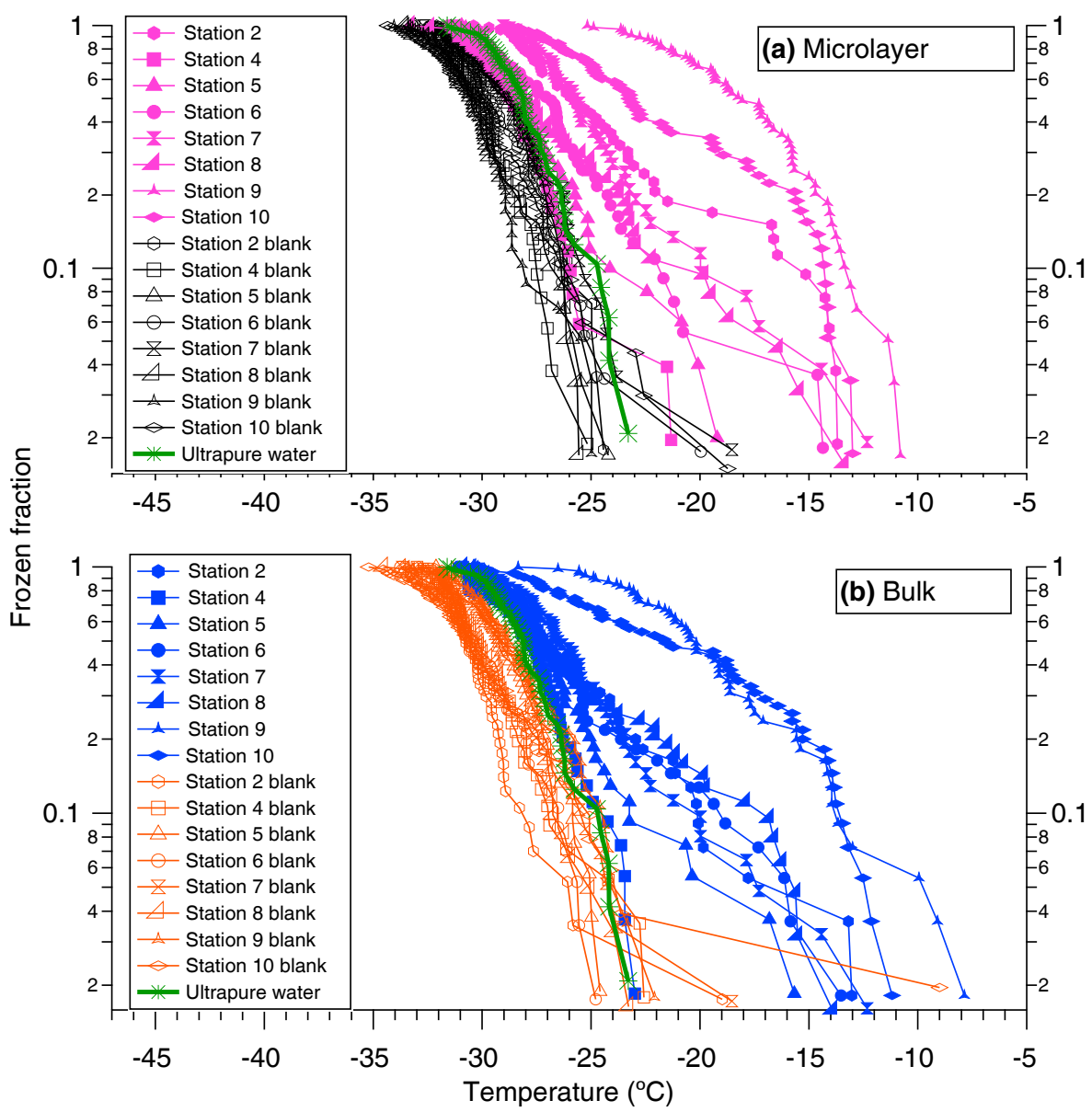

Figure 2. Fraction of droplets frozen (in the immersion mode) vs. temperature. Panels (a) and (b) correspond to the microlayer and bulk seawater, respectively. Each set of line and markers represents the results for three repeat experiments of a sample or blank, adding up to a total of between 45 and 60 freezing events in each set. Also included are the respective blank samples and ultrapure water. Each data point corresponds to a single freezing event in the experiments. All microlayer and bulk seawater freezing points have been corrected for freezing point depression to account for dissolved salts in seawater (Sect. 2.2.4). The uncertainty in temperature is not shown but is $\pm 0.3^{\circ} \mathrm{C}$.

(15 mW output; blue), using Expo32 v1.2b software (Beckman Coulter).

\subsection{Dimethylsulfide (DMS) measurements}

Concentrations of DMS were measured on-board the ship within approximately $2 \mathrm{~h}$ of sampling. The samples were analysed using gas chromatography following purging and cryotrapping according to the protocol described in Lizotte et al. (2008).

\subsection{Statistical analysis}

Pearson correlation analysis was applied to many of the variables measured in this study to compute correlation coefficients $(R)$. Here we use the scheme from Dancey and Reidy (2002) in which correlations with $R$ values of $0.1-$ $0.3,0.4-0.6$, and $0.7-0.9$ are classified as weak, moderate, and strong, respectively. $P$ values were also calculated to de-
Table 2. Correlation analyses between chemical or physical properties of bulk seawater and $T_{10}$ values for the bulk seawater samples. Numbers in bold represent correlations that are statistically significant $(p<0.05)$.

\begin{tabular}{lrrr}
\hline Chemical and physical properties & \multicolumn{3}{c}{$T_{10}$ value } \\
& $R$ & $p$ & $n$ \\
\hline Dimethylsulfide concentration & -0.6 & 0.074 & 8 \\
Bacterial abundance & -0.4 & 0.189 & 6 \\
Phytoplankton abundance & -0.5 & 0.138 & 6 \\
Temperature & 0.1 & 0.381 & 8 \\
pH & -0.1 & 0.372 & 8 \\
Salinity & $-\mathbf{0 . 7}$ & $\mathbf{0 . 0 2 0}$ & $\mathbf{8}$ \\
\hline
\end{tabular}

termine if the correlations were statistically significant at the $95 \%$ confidence level $(p<0.05)$. 


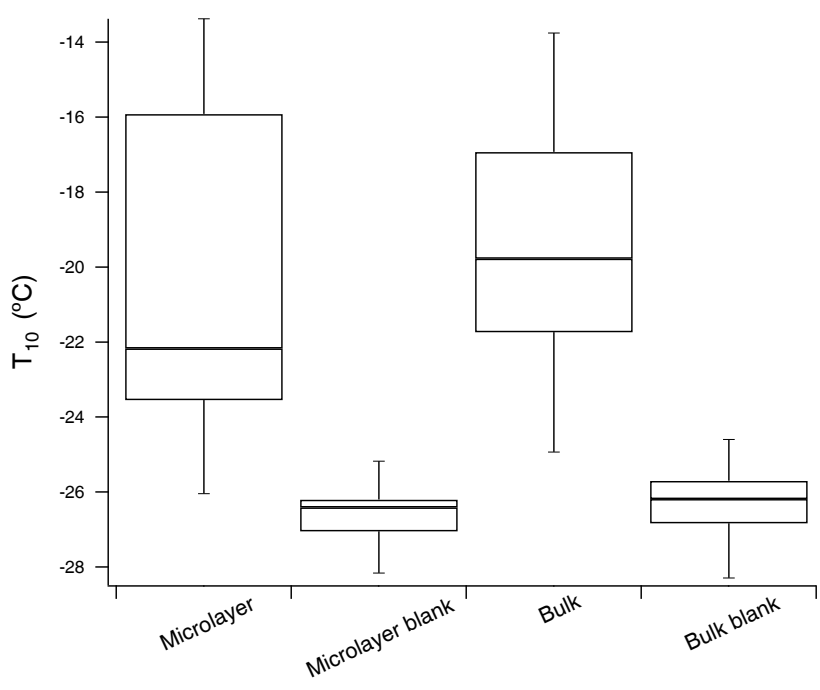

Figure 3. Temperature at which $10 \%$ of droplets had frozen $\left(T_{10}\right)$ for microlayer and bulk seawater samples. All data have been corrected for freezing point depression. Boxes represent the 25th, 50th, and 75th percentiles, and whiskers represent the minima and maxima.

\section{Results and discussion}

\subsection{INPs in the microlayer and bulk seawater}

The fraction of droplets frozen in the immersion mode for both the unfiltered microlayer and bulk seawater samples is shown in Fig. 2. In this figure the blanks refer to the freezing properties of the sample after $0.02 \mu \mathrm{m}$ filtration. The blanks may still contain some INPs since some particles $<0.02 \mu \mathrm{m}$ in diameter can act as INPs (Dreischmeier et al., 2017; O'Sullivan et al., 2015). The freezing properties of the blanks (after correction for freezing point depression by the salts) are similar to or lower than the freezing properties of ultrapure water, which are also shown in Fig. 2. The frozen fraction curves for each station fall at warmer temperatures than their respective blanks, indicating that the microlayer and bulk seawater samples from all stations contained INPs. Box plots of the $T_{10}$ values for the blanks and the microlayer and bulk seawater samples are shown in Fig. 3 , in which $T_{10}$ represents the temperatures at which $10 \%$ of droplets had frozen. Figure 3 shows that the interquartile range of freezing temperatures for the samples is higher than the interquartile range of freezing temperatures for the blanks, further illustrating that INPs were present in the microlayer and bulk seawater samples.

The freezing curves varied significantly from sample to sample (Fig. 2). To understand this variability, we investigated correlations between the $T_{10}$ values for the bulk seawater samples and the chemical and physical properties of the bulk seawater (DMS concentration, bacterial and phytoplankton abundance, seawater temperature, $\mathrm{pH}$, and salin- ity). Correlation coefficients were not statistically significant $(p>0.05)$, except in the case of salinity (Table 2 and Fig. S1 in the Supplement). A strong negative correlation $(R=-0.7$, $p=0.02$ ) was observed between salinity and the $T_{10}$ values (corrected for freezing depression by the salts). This suggests that more INPs were found in less saline waters. A similar trend was observed for $T_{50}$ values, in which $T_{50}$ represents the temperatures at which $50 \%$ of droplets had frozen (Table S2). One possible explanation is that the INPs were associated with melting sea ice. Materials such as algal aggregates, sea ice diatoms, and extracellular polymeric substances can be released into the ocean upon sea ice melting (Assmy et al., 2013; Boetius et al., 2015; Fernández-Méndez et al., 2014) and might be potential sources of the INPs observed in this study. Also interesting, a strong positive correlation was observed between salinity and bacterial abundance $(R=0.76, p=0.039)$. Consistent with these results, Galgani et al. (2016) observed a higher concentration of bacteria in the open sea (which had a higher salinity) compared to melt ponds (which had a lower salinity). Another possible explanation for the strong negative correlation between salinity and freezing temperatures is a non-colligative effect not accounted for in the corrections for freezing temperature depression discussed in Sect. 2.2.4. However, as mentioned in Sect. 2.2.4, non-colligative effects have not been observed in previous immersion freezing studies with sodium chloride solutions (Alpert et al.,, 2011a, b; Knopf et al., 2011; Zobrist et al., 2008) or seawater (Wilson et al., 2015).

The concentration of INPs as a function of temperature, $[\operatorname{INP}(T)]$, for the microlayer samples analysed in this study is shown in Fig. 4a. Also included in Fig. 4a are results from Wilson et al. (2015) for the microlayer samples they collected at the locations shown in Fig. 1a. Concentrations of INPs in microlayer samples at stations 2,9 , and 10 overlap with the INP concentrations observed by Wilson et al. (2015) in the Atlantic. However, the INP concentrations in the microlayer measured by Wilson et al. (2015) to the east of Greenland are higher than the concentrations measured here.

Figure $4 \mathrm{~b}$ shows the concentrations of INPs as a function of temperature for the bulk seawater samples. Also included in Fig. 4b are results from other studies (see Fig. 1b for locations) that measured INPs in samples of bulk seawater or samples containing a mixture of the microlayer and bulk seawater. The range of concentrations observed in our studies agrees well with the range observed by Schnell and Vali (1975), Schnell (1977), and Wilson et al. (2015) (both Arctic and Atlantic). Note that the bulk seawater freezing data from Wilson et al. (2015) were at the detection limit of their instrument; therefore, their INP concentrations for bulk seawater should be considered upper limits.

A strong positive correlation $(R=0.9, p=0.002)$ between the freezing properties of the microlayer and the freezing properties of the bulk seawater was observed in the current study. Shown in Fig. 5a is a correlation plot between the $T_{10}$ values from the microlayer and bulk seawater sam- 


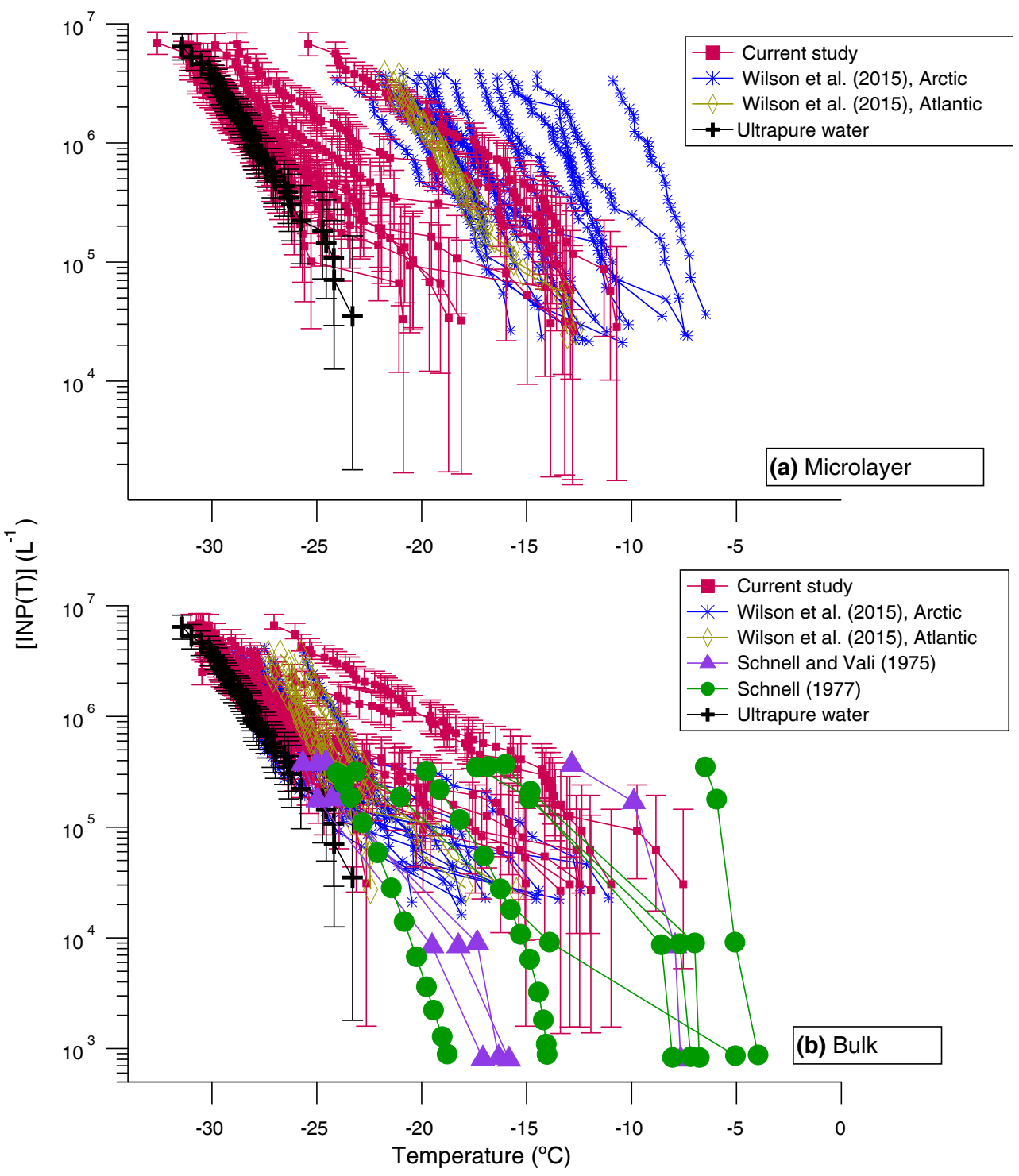

Figure 4. The concentrations of INPs, $[\operatorname{INP}(T)]$, in the microlayer (a) and bulk seawater samples (b). All data, including those from other studies, are corrected for freezing point depression. Upper and lower limits of $[\operatorname{INP}(T)]\left(\mathrm{L}^{-1}\right)$ associated with the current study describe the statistical uncertainty due to the limited number of nucleation events observed in the freezing experiments (Koop et al., 1997).

ples. The data points, except for one, fall upon the $1: 1$ line, if the uncertainties in the measurements are considered. In contrast, Wilson et al. (2015) found significantly more INPs in the microlayer than in bulk seawater (Fig. 5b) in both their Arctic and Atlantic samples. Figure 5 also shows correlation plots for bacterial abundance in the microlayer and bulk seawater for this study (Fig. 5c) and from Wilson et al. (2015) (Fig. 5d). Similar bacterial abundances were observed in the microlayer and bulk seawater in the current study, whereas Wilson et al. (2015) found a higher bacterial abundance in the microlayer compared to the bulk seawater in most samples (Fig. 5d).
The differences between the results in the current study and the results from Wilson et al. (2015) may be, in part, related to sampling techniques. In the current study, the bulk seawater was sampled from a depth of $0.5 \mathrm{~m}$ while Wilson et al. (2015) sampled from a depth of 2-5 m. In addition, in the current study the glass plate technique used collected a layer that was up to $220 \mu \mathrm{m}$ thick, while Wilson et al. (2015) used a hydrophilic Teflon film on a rotating drum fitted to a remote-controlled sampling catamaran which collects a microlayer of thickness between 6 to $83 \mu \mathrm{m}$ (Knulst et al., 2003). Other studies have shown that different sampling techniques lead to different measured enrichments of the microlayer. Aller et al. (2017) compared the enrichments 

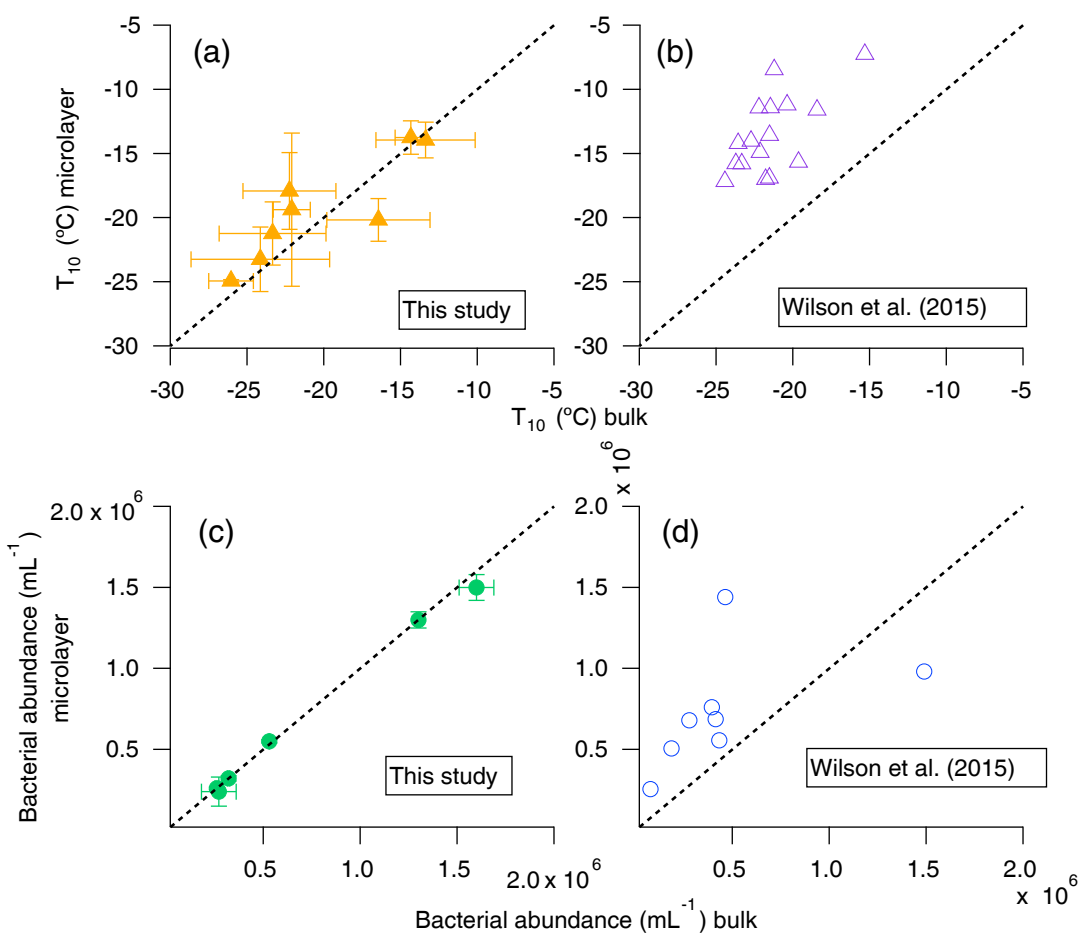

Figure 5. Correlation plots with a $1: 1$ line for reference. Panel (a) shows freezing temperatures for microlayer and bulk seawater samples in this study. $T_{10}$ represents the freezing temperatures at which $10 \%$ of the droplets had frozen. All error bars represent the $95 \%$ confidence intervals of the $T_{10}$ values from three replicate experiments. All data have been corrected for freezing point depression. Panel (b) shows $T_{10}$ values for microlayer and bulk seawater samples from Wilson et al. (2015). All data have been corrected for freezing point depression. The reported $T_{10}$ values for their bulk samples should be considered upper limits since their bulk freezing data were at the detection limit of their instrument. Panel (c) shows bacterial abundance in the microlayer and bacterial abundance in the bulk seawater in this study. There was only one reliable microlayer sample from station 7 for bacterial abundance; therefore, the percentage error for this station was assigned the maximum percentage error from the other bacterial abundance. Panel (d) shows bacterial abundance in the microlayer and bacterial abundance in the bulk seawater from Wilson et al. (2015).

of the microlayer determined with the glass plate and a hydrophilic Teflon film on a rotating drum. They observed an enrichment (by a factor of approximately 2 ) of bacteria in the microlayer when using the rotating drum, but no enrichment when using the glass plate technique. In addition, they observed an enrichment of transparent exopolymer material in the microlayer when using the rotating drum, but a smaller enrichment was observed when using the glass plate technique. Note that Aller et al. (2017) allowed seawater to stand in a 250 gallon tank for $1 \mathrm{~h}$ before sampling the microlayer with a glass plate, whereas the microlayer sampled with the rotating drum was taken directly from the ocean. Additional studies are needed to determine if the methodology used to sample the microlayer and bulk seawater strongly influences measured INP concentrations.

The differences between the results in the current study and the results from Wilson et al. (2015) may also be related to differences in the state of the ocean at the time of sampling. To investigate this we compared monthly average chlorophyll $a$ concentrations for both studies. As illustrated in Figs. S2-S4, a clear difference between chlorophyll $a$ con- centrations in the current study and the Wilson et al. (2015) study was not observed.

Wind speed could also affect the stability of the microlayer and explain differences between results from the current study and the Wilson et al. (2015) study. Previous studies suggest that a microlayer may be stable up to the global average wind speed of $6.6 \mathrm{~m} \mathrm{~s}^{-1}$ (Wurl et al., 2011). During the current study, sampling was carried out at wind speeds ranging from 0.7 to $6.7 \mathrm{~m} \mathrm{~s}^{-1}$, while Wilson et al. (2015) carried out sampling at wind speeds ranging from 1.2 to $5.9 \mathrm{~m} \mathrm{~s}^{-1}$. The similar wind speeds in both studies and the fact that almost all sampling was carried out with wind speeds less than the global average suggests that the observed differences in INP concentrations are not due to wind speeds.

\subsection{Properties of the INPs}

\subsubsection{Heat-labile biological material}

The frozen fraction curves of samples before and after heating to a temperature of $100^{\circ} \mathrm{C}$ are shown in Fig. 6. For seven out of eight of the microlayer samples, and all of the bulk 


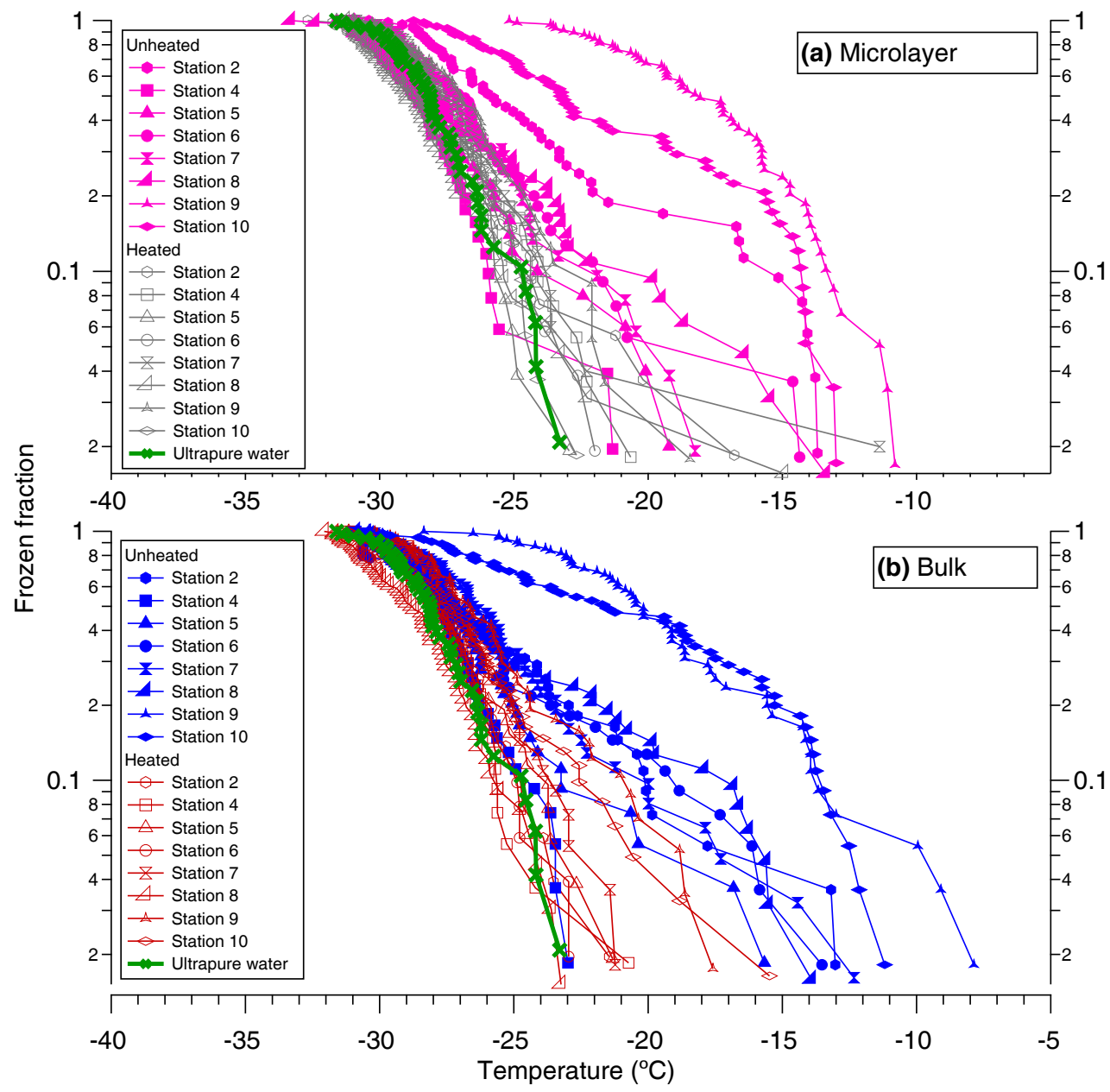

Figure 6. Effect of heating on the frozen fraction for unfiltered samples from microlayer (a) and bulk seawater (b). Each data point corresponds to one droplet freezing event, and all data have been corrected for freezing point depression. The uncertainty in temperature is not shown but is $\pm 0.3^{\circ} \mathrm{C}$.

samples, the frozen fraction curves are shifted to colder temperatures after heating. These results suggest that the INPs in most cases are heat-labile biological material, consistent with previous measurements of the properties of INPs in the microlayer (Wilson et al., 2015) and bulk seawater (Schnell and Vali, 1975, 1976; Schnell, 1977).

\subsubsection{Size of INPs}

The $T_{10}$ values as a function of filter pore size $(0.02,0.2$, and $10 \mu \mathrm{m}$ ) are shown in Fig. 7. For over half the samples (microlayer samples at stations 4 and 5, bulk samples at station 6 and bulk and microlayer samples at stations 7,9, and 10) the sizes of the INPs were clearly between 0.02 and $0.2 \mu \mathrm{m}$, as the $T_{10}$ values significantly decreased when the samples were passed through a $0.02 \mu \mathrm{m}$ filter but not when passed through a $0.2 \mu \mathrm{m}$ filter. For the other samples (bulk samples at stations 4 and 5 , microlayer samples at station 6 , and microlayer and bulk samples at stations 2 and 8), the uncertainties were too large to draw a clear conclusion about the effect of filtration. Plots of the fraction of droplets frozen vs. temperature for samples filtered with a $0.02,0.2$, and $10 \mu \mathrm{m}$ filter are shown in Fig. S5 and are consistent with the results shown in Fig. 7.

The $0.02-0.2 \mu \mathrm{m}$ size range for the INPs identified here is consistent with previous studies of INPs in the microlayer or bulk seawater. Wilson et al. (2015) concluded that INPs in the microlayer were between 0.02 and $0.2 \mu \mathrm{m}$ in size. Rosinski et al. (1986) found that ice freezing nuclei in aerosol of marine origin were below $0.5 \mu \mathrm{m}$ in size. Schnell and Vali (1975) found ocean-derived ice nuclei to be below $1 \mu \mathrm{m}$ in size.

The size of marine bacteria or phytoplankton (excluding femtoplankton) is typically greater than $0.2 \mu \mathrm{m}$ (Burrows et al., 2013; Sieburth et al., 1978); hence, whole cell marine bacteria are unlikely to be the source of the INPs identified here. Furthermore, correlations between INP concentrations and bacterial or phytoplankton abundance were not statistically significant ( $p$ values $>0.05$; see the Supple- 


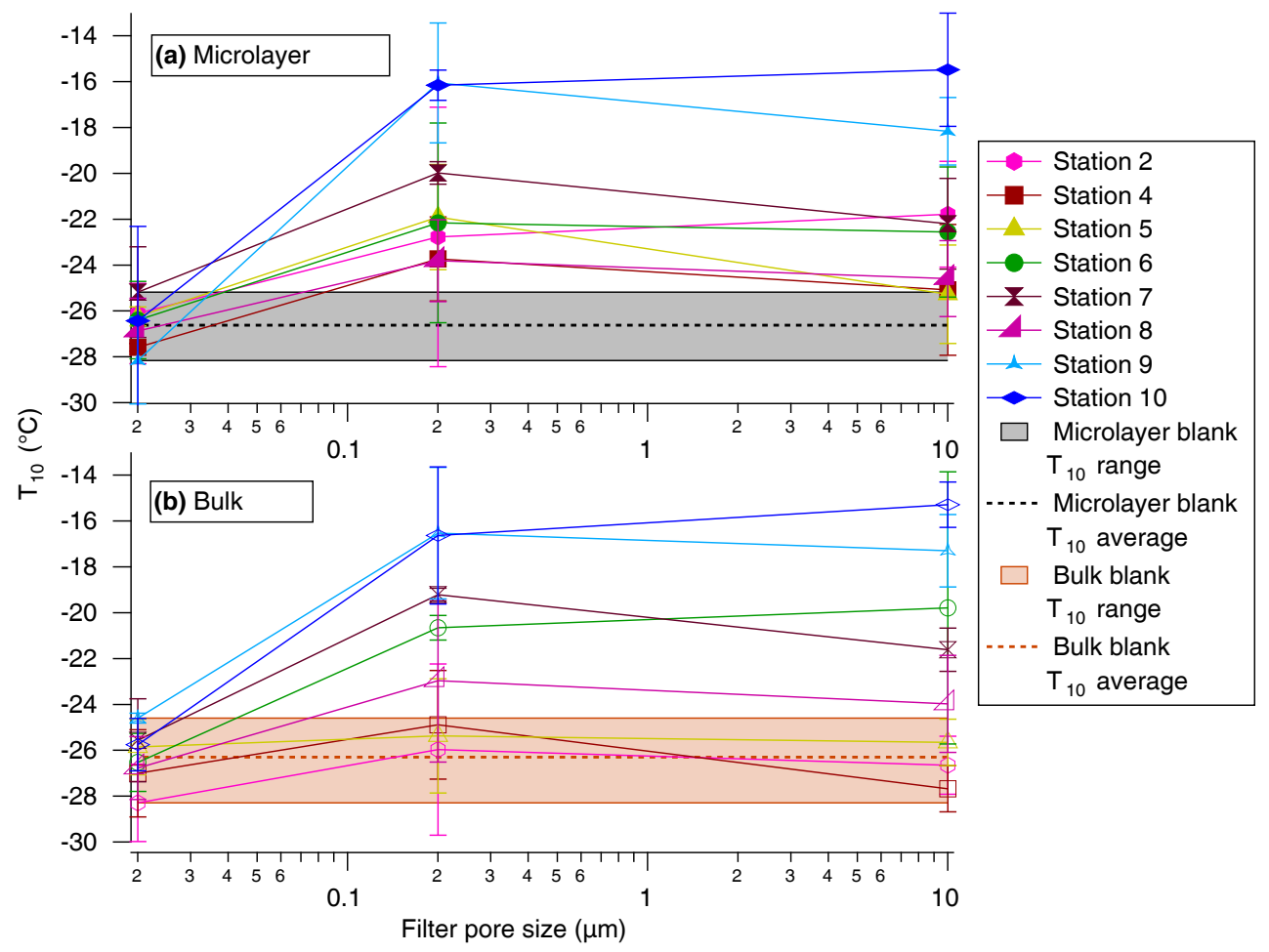

Figure 7. Temperature at which $10 \%$ of the droplets froze $\left(T_{10}\right)$ as a function of filter pore size in microlayer samples (a) and bulk seawater samples (b). Filter pore sizes were 10, 0.2, and $0.02 \mu \mathrm{m}$. Error bars are the $95 \%$ confidence intervals of the $T_{10}$ from three replicate experiments. All data have been corrected for freezing point depression.

ment, Table S3). This is consistent with the suggestion that whole cells are not the source of the INPs. Potential sources of the INPs observed in this study include ultramicrobacteria, viruses, phytoplankton exudates, or bacteria exudates (Ladino et al., 2016; Wilson et al., 2015).

\section{Summary and conclusions}

Concentrations of INPs in the microlayer and bulk seawaters at eight different stations in the Canadian Arctic were determined. Results showed that the INPs were ubiquitous in the microlayer and bulk seawater and that freezing temperatures as high as $-14{ }^{\circ} \mathrm{C}$ were observed in both the microlayer and bulk seawater. A strong negative correlation $(R=-0.7$, $p=0.02$ ) was observed between salinity and freezing temperatures (after correction for freezing depression by salts). One possible explanation is that INPs were associated with melting sea ice. The concentration of INPs in the bulk seawater was in good agreement with concentrations observed in bulk samples at several other locations in the Northern Hemisphere. The concentrations of INPs in the microlayer were consistent with concentrations observed by Wilson et al. (2015) off the coast of North America. Heating the samples substantially reduced the INPs' activity, suggesting that heat-labile biological materials were the likely source of that activity. Filtration of the samples showed that the INPs were between 0.02 and $0.2 \mu \mathrm{m}$, implying that the ice-active heat-labile biological material was likely ultramicrobacteria, viruses, or extracellular material, rather than whole cells.

We conclude that the concentrations and properties of INPs in the microlayer and bulk seawater in the Canadian Arctic are similar to other locations previously studied. However, there were some important differences. On average, the concentration of INPs in the microlayer in the current study was lower than the average concentration of INPs measured by Wilson et al. (2015). These differences could not be explained by chlorophyll $a$ concentrations from satellite measurements. In addition, similar concentrations of INPs in the microlayer and bulk seawater were observed here, while Wilson et al. (2015) observed significant enrichment of INPs in the microlayer compared to the bulk seawater. The differences may be related to sampling techniques, but they could also be due to the oceanic state during sampling. Further studies are needed to understand how measured concentrations of INPs in the microlayer and bulk seawater depend on sampling techniques. Further studies are also needed to understand how measured concentrations of INPs in the microlayer and bulk seawater depend on oceanic variables, particularly changing sea ice distributions.

As sea ice in the Arctic continues to decrease, the microlayer and bulk seawater could play a larger role in the overall 
atmospheric INP population in this region. Future modelling studies are needed to determine the magnitude of the effect this INP source has on cloud microphysics in the Arctic region and how it might change as sea ice distributions change.

Data availability. Underlying material and related items for this manuscript are located in the Supplement.

\section{The Supplement related to this article is available online at https://doi.org/10.5194/acp-17-10583-2017- supplement.}

Competing interests. The authors declare that they have no conflict of interest.

Special issue statement. This article is part of the special issue "NETCARE (Network on Aerosols and Climate: Addressing Key Uncertainties in Remote Canadian Environments) (ACP/AMT/BG inter-journal SI)". It is not associated with a conference.

Acknowledgements. We would like to thank the scientists, officers, and crew of the CCGS Amundsen for their support during the expedition; Mélanie Simard and Claude Belzile for help with analysis; and Dennis A. Hansell and Wenhao Chen for providing reference materials. We would also like to thank the Natural Sciences and Engineering Research Council of Canada and Fisheries and Oceans Canada for funding. Benjamin J. Murray acknowledges support from the European Research Council, (ERC 648661 MarineIce) and the Natural Environment Research Council (NERC, NE/K004417/1).

Edited by: Daniel J. Cziczo

Reviewed by: two anonymous referees

\section{References}

Aller, J. Y., Radway, J. C., Kilthau, W. P., Bothe, D. W., Wilson, T. W., Vaillancourt, R. D., Quinn, P. K., Coffman, D. J., Murray, B. J., and Knopf, D. A.: Size-resolved characterization of the polysaccharidic and proteinaceous components of sea spray aerosol, Atmos. Environ., 154, 331-347, https://doi.org/10.1016/j.atmosenv.2017.01.053, 2017.

Alpert, P. A., Aller, J. Y., and Knopf, D. A.: Ice nucleation from aqueous $\mathrm{NaCl}$ droplets with and without marine diatoms, Atmos. Chem. Phys., 11, 5539-5555, https://doi.org/10.5194/acp11-5539-2011, 2011a.

Alpert, P. A., Aller, J. Y., and Knopf, D. A.: Initiation of the ice phase by marine biogenic surfaces in supersaturated gas and supercooled aqueous phases, Phys. Chem. Chem. Phys., 13, 19882-19894, https://doi.org/10.1039/c1cp21844a, 2011b.
Assmy, P., Ehn, J. K., Fernández-Méndez, M., Hop, H., Katlein, C., Sundfjord, A., Bluhm, K., Daase, M., Engel, A., Fransson, A., Granskog, M. A., Hudson, S. R., Kristiansen, S., Nicolaus, M., Peeken, I., Renner, A. H. H., Spreen, G., Tatarek, A., and Wiktor, J.: Floating ice-algal aggregates below melting Arctic Sea ice, PLoS One, 8, 1-13, https://doi.org/10.1371/journal.pone.0076599, 2013.

Belzile, C., Brugel, S., Nozais, C., Gratton, Y., and Demers, S.: Variations of the abundance and nucleic acid content of heterotrophic bacteria in Beaufort Shelf waters during winter and spring, J. Marine Syst., 74, 946-956, https://doi.org/10.1016/j.jmarsys.2007.12.010, 2008.

Blanchard, D. C.: Sea-to-air transport of surface active material, Science, 146, 396-397, 1964.

Boetius, A., Anesio, A. M., Deming, J. W., Mikucki, J., and Rapp, J. Z.: Microbial ecology of the cryosphere?: sea ice and glacial habitats, Nat. Rev. Microbiol., 13, 677-690, https://doi.org/10.1038/nrmicro3522, 2015.

Burrows, S. M., Hoose, C., Pöschl, U., and Lawrence, M. G.: Ice nuclei in marine air: biogenic particles or dust?, Atmos. Chem. Phys., 13, 245-267, https://doi.org/10.5194/acp-13-2452013, 2013.

Christner, B. C., Cai, R., Morris, C. E., McCarter, K. S., Foreman, C. M., Skidmore, M. L., Montross, S. N., and Sands, D. C.: Geographic, seasonal, and precipitation chemistry influence on the abundance and activity of biological ice nucleators in rain and snow, P. Natl. Acad. Sci. USA, 105, 18854-18859, https://doi.org/10.1073/pnas.0809816105, 2008.

Csuros, M.: Environmental Sampling and Analysis for Technicians, Lewis Publisher, New York, 1994.

Dancey, C. P. and Reidy, J.: Statistics Without Maths for Psychology, 2nd edn., Pearson Education Limited, Harlow, England, 2002.

DeMott, P. J., Prenni, A. J., Liu, X., Kreidenweis, S. M., Petters, M. D., Twohy, C. H., Richardson, M. S., Eidhammer, T., and Rogers, D. C.: Predicting global atmospheric ice nuclei distributions and their impacts on climate, P. Natl. Acad. Sci. USA, 107, 11217-11222, https://doi.org/10.1073/pnas.0910818107, 2010.

DeMott, P. J., Hill, T. C. J., McCluskey, C. S., Prather, K. A., Collins, D. B., Sullivan, R. C., Ruppel, M. J., Mason, R. H., Irish, V. E., Lee, T., Hwang, C. Y., Rhee, T. S., Snider, J. R., McMeeking, G. R., Dhaniyala, S., Lewis, E. R., Wentzell, J. J. B., Abbatt, J., Lee, C., Sultana, C. M., Ault, A. P., Axson, J. L., Diaz Martinez, M., Venero, I., Santos-Figueroa, G., Stokes, M. D., Deane, G. B., Mayol-Bracero, O. L., Grassian, V. H., Bertram, T. H., Bertram, A. K., Moffett, B. F., and Franc, G. D.: Sea spray aerosol as a unique source of ice nucleating particles, P. Natl. Acad. Sci. USA, 113, 5797-5803, https://doi.org/10.1073/pnas.1514034112, 2015.

Dreischmeier, K., Budke, C., Wiehemeier, L., Kottke, T., and Koop, T.: Boreal pollen contain ice-nucleating as well as icebinding "antifreeze" polysaccharides, Sci. Rep.-UK, 7, 41890, https://doi.org/10.1038/srep41890, 2017.

Fahlgren, C., Gómez-Consarnau, L., Zábori, J., Lindh, M. V., Krejci, R., Mårtensson, E. M., Nilsson, D., and Pinhassi, J.: Seawater mesocosm experiments in the Arctic uncover differential transfer of marine bacteria to aerosols, Env. Microbiol. Rep., 7, 460-470, https://doi.org/10.1111/1758-2229.12273, 2015. 
Fall, R. and Schnell, R. C.: Association of an ice-nucleating pseudomonad with cultures of the marine dinoflagellate, heterocapsa niei, J. Mar. Res., 43, 257-265, 1985.

Fernández-Méndez, M., Wenzhöfer, F., Peeken, I., Sørensen, H. L., Glud, R. N., and Boetius, A.: Composition, buoyancy regulation and fate of ice algal aggregates in the Central Arctic Ocean, PLoS One, 9, e107452, https://doi.org/10.1371/journal.pone.0107452, 2014.

Galgani, L., Piontek, J., and Engel, A.: Biopolymers form a gelatinous microlayer at the air-sea interface when Arctic sea ice melts, Sci. Rep.-UK, 6, 29465, https://doi.org/10.1038/srep29465, 2016.

Harrington, J. Y., Reisin, T., Cotton, W. R., and Kreidenweis, S. M.: Cloud resolving simulations of Arctic stratus Part II: Transition-season clouds, Atmos. Res., 51, 45-75, https://doi.org/10.1016/S0169-8095(98)00098-2, 1999.

Harvey, G. W. and Burzell, L. A.: A simple microlayer method for small samples, Limnol. Oceanogr.-Meth., 17, 156-157, 1972.

Herbert, R. J., Murray, B. J., Dobbie, S. J., and Koop, T.: Sensitivity of liquid clouds to homogeneous freezing parameterizations, Geophys. Res. Lett., 42, 1599-1605, 2015.

Hill, T. C. J., DeMott, P. J., Tobo, Y., Fröhlich-Nowoisky, J., Moffett, B. F., Franc, G. D., and Kreidenweis, S. M.: Sources of organic ice nucleating particles in soils, Atmos. Chem. Phys., 16, 7195-7211, https://doi.org/10.5194/acp-16-7195-2016, 2016.

Jiang, H., Cotton, W. R., Pinto, J. O., Curry, J. A., and Weissbluth, M. J.: Cloud resolving simulations of mixed-phase arctic stratus observed during BASE: sensitivity to concentration of ice crystals and large-scale heat and moisture advection, J. Atmos. Sci., 57, 2105-2117, https://doi.org/10.1175/15200469(2000)057<2105:CRSOMP>2.0.CO;2, 2000.

Knopf, D. A. and Forrester, S. M.: Freezing of water and aqueous $\mathrm{NaCl}$ droplets coated by organic monolayers as a function of surfactant properties and water activity, J. Phys. Chem. A, 115, 5579-5591, https://doi.org/10.1021/jp2014644, 2011.

Knopf, D. A., Alpert, P. A., Wang, B., and Aller, J. Y.: Stimulation of ice nucleation by marine diatoms, Nat. Geosci., 4, 88-90, https://doi.org/10.1038/ngeo1037, 2011.

Knulst, J. C., Rosenberger, D., Thompson, B., and Paatero, J.: Intensive sea surface microlayer investigations of open leads in the pack ice during Arctic Ocean 2001 expedition, Langmuir, 19, 10194-10199, https://doi.org/10.1021/la035069+, 2003.

Koop, T. and Murray, B. J.: A physically constrained classical description of the homogeneous nucleation of ice in water, J. Chem. Phys., 145, 211915, https://doi.org/10.1063/1.4962355, 2016.

Koop, T. and Zobrist, B.: Parameterizations for ice nucleation in biological and atmospheric systems, Phys. Chem. Chem. Phys., 11, 10839-10850, https://doi.org/10.1039/b914289d, 2009.

Koop, T., Luo, B., Biermann, U. M., Crutzen, P. J., and Peter, T.: Freezing of $\mathrm{HNO}_{3} / \mathrm{H}_{2} \mathrm{SO}_{4} / \mathrm{H}_{2} \mathrm{O}$ solutions at stratospheric temperatures: nucleation statistics and experiments, J. Phys. Chem. A, 101, 1117-1133, https://doi.org/10.1021/jp9626531, 1997.

Koop, T., Ng, H. P., Molina, L. T., and Molina, M. J.: A new optical technique to study aerosol phase transitions: the nucleation of ice from $\mathrm{H}_{2} \mathrm{SO}_{4}$ aerosols, J. Phys. Chem. A, 102, 8924-8931, https://doi.org/10.1021/jp9828078, 1998.

Ladino, L. A., Yakobi-Hancock, J. D., Kilthau, W. P., Mason, R. H., Si, M., Li, J., Miller, L. A., Schiller, C. L., Huffman, J. A., Aller, J. Y., Knopf, D. A., Bertram, A. K., and Abbatt, J. P. D.: Addressing the ice nucleating abilities of marine aerosol: a combination of deposition mode laboratory and field measurements, Atmos. Environ., 132, 1-10, https://doi.org/10.1016/j.atmosenv.2016.02.028, 2016.

Liss, P. S. and Duce, R. A.: The sea Surface and Global Change, Cambridge University Press, Cambridge, 1997.

Lizotte, M., Levasseur, M., Scarratt, M. G., Michaud, S., Merzouk, A., Gosselin, M., and Pommier, J.: Fate of dimethylsulfoniopropionate (DMSP) during the decline of the northwest Atlantic Ocean spring diatom bloom, Aquat. Microb. Ecol., 52, 159-173, https://doi.org/10.3354/ame01232, 2008.

Lohmann, U.: A glaciation indirect aerosol effect caused by soot aerosols, Geophys. Res. Lett., 29, 1052, https://doi.org/10.1029/2001gl014357, 2002.

Lohmann, U. and Feichter, J.: Global indirect aerosol effects: a review, Atmos. Chem. Phys., 5, 715-737, https://doi.org/10.5194/acp-5-715-2005, 2005.

Marie, D., Simon, N., and Vaulot, D.: Phytoplankton cell counting by flow cytometry, in: Algal Culturing Techniques, Academic Press, London, 253-267, 2005.

Murray, B. J., O'Sullivan, D., Atkinson, J. D., and Webb, M. E.: Ice nucleation by particles immersed in supercooled cloud droplets, Chem. Soc. Rev., 41, 6519-6554, https://doi.org/10.1039/c2cs35200a, 2012.

O’Sullivan, D., Murray, B. J., Ross, J. F., Whale, T. F., Price, H. C., Atkinson, J. D., Umo, N. S., and Webb, M. E.: The relevance of nanoscale biological fragments for ice nucleation in clouds, Sci. Rep.-UK, 5, 8082, https://doi.org/10.1038/srep08082, 2015.

Parsons, M. T., Mak, J., Lipetz, S. R., and Bertram, A. K.: Deliquescence of malonic, succinic, glutaric, and adipic acid particles, J. Geophys. Res., 109, 1-8, https://doi.org/10.1029/2003JD004075, 2004.

Prather, K. A., Bertram, T. H., Grassian, V. H., Deane, G. B., Stokes, M. D., Demott, P. J., Aluwihare, L. I., Palenik, B. P., Azam, F., Seinfeld, J. H., Moffet, R. C., Molina, M. J., Cappa, C. D., Geiger, F. M., Roberts, G. C., Russell, L. M., Ault, A. P., Baltrusaitis, J., Collins, D. B., Corrigan, C. E., Cuadra-Rodriguez, L. A., Ebben, C. J., Forestieri, S. D., Guasco, T. L., Hersey, S. P., Kim, M. J., Lambert, W. F., Modini, R. L., Mui, W., Pedler, B. E., Ruppel, M. J., Ryder, O. S., Schoepp, N. G., Sullivan, R. C., and Zhao, D.: Bringing the ocean into the laboratory to probe the chemical complexity of sea spray aerosol, P. Natl. Acad. Sci. USA, 110, 7550-7555, https://doi.org/10.1073/pnas.1300262110, 2013.

Rosinski, J., Haagenson, P. L., Nagamoto, C. T., and Parungo, F.: Ice-forming nuclei of maritime origin, J. Aerosol Sci., 17, 23 46, https://doi.org/10.1016/0021-8502(86)90004-2, 1986.

Rosinski, J., Haagenson, P. L., Nagamoto, C. T., Quintana, B., Parungo, F., and Hoyt, S. D.: Ice-forming nuclei in air masses over the Gulf of Mexico, J. Aerosol Sci., 19, 539-551, 1988.

Schnell, R. C.: Ice nuclei in seawater, fog water and marine air off the coast of Nova Scotia: summer 1975, J. Atmos. Sci., 34, 12991305, 1977.

Schnell, R. C. and Vali, G.: Freezing nuclei in marine waters, Tellus, 27, 321-323, https://doi.org/10.3402/tellusa.v27i3.9911, 1975.

Schnell, R. C. and Vali, G.: Biogenic ice nuclei: Part I. Terrestrial and Marine Sources, J. Atmos. Sci., 33, 1554-1564, https://doi.org/10.1175/15200469(1976)033<1554:BINPIT>2.0.CO;2, 1976. 
Sieburth, J. M., Smetacek, V., and Lenz, J.: Pelagic ecosystem structure: heterotrophic compartments of the plankton and their relationship to plankton size fractions, Limnol. Oceanogr., 23, 12561263, https://doi.org/10.4319/lo.1978.23.6.1256, 1978.

Tan, I., Storelvmo, T., and Zelinka, M. D.: Observational constraints on mixed-phase clouds imply higher climate sensitivity, Science, 352, 224-227, 2016.

Tremblay, G., Belzile, C., Gosselin, M., Poulin, M., Roy, S., and Tremblay, J. É.: Late summer phytoplankton distribution along a $3500 \mathrm{~km}$ transect in Canadian Arctic waters: strong numerical dominance by picoeukaryotes, Aquat. Microb. Ecol., 54, 55-70, https://doi.org/10.3354/ame01257, 2009.

Vali, G.: Quantitative evaluation of experimental results on the heterogeneous freezing nucleation of supercooled liquids, J. Atmos. Sci., 28, 402-409, 1971.

Vali, G., Christensen, M., Fresh, R. W., Galyan, E. L., Maki, L. R., and Schnell, R. C.: Biogenic ice nuclei. Part II: Bacterial sources, J. Atmos. Sci., 33, 1565-1570, https://doi.org/10.1175/15200469(1976)033<1565:BINPIB>2.0.CO;2, 1976.

Vergara-Temprado, J., Murray, B. J., Wilson, T. W., O’Sullivan, D., Browse, J., Pringle, K. J., Ardon-Dryer, K., Bertram, A. K., Burrows, S. M., Ceburnis, D., DeMott, P. J., Mason, R. H., O’Dowd, C. D., Rinaldi, M., and Carslaw, K. S.: Contribution of feldspar and marine organic aerosols to global ice nucleating particle concentrations, Atmos. Chem. Phys., 17, 3637-3658, https://doi.org/10.5194/acp-17-3637-2017, 2017.

Wang, X., Sultana, C. M., Trueblood, J., Hill, T. C. J., Malfatti, F., Lee, C., Laskina, O., Moore, K. A., Beall, C. M., McCluskey, C. S., Cornwell, G. C., Zhou, Y., Cox, J. L., Pendergraft, M. A., Santander, M. V., Bertram, T. H., Cappa, C. D., Azam, F., DeMott, P. J., Grassian, V. H., and Prather, K. A.: Microbial control of sea spray aerosol composition: a tale of two blooms, ACS Cent. Sci., 1, 124-131, https://doi.org/10.1021/acscentsci.5b00148, 2015.

Whale, T. F., Murray, B. J., O'Sullivan, D., Wilson, T. W., Umo, N. S., Baustian, K. J., Atkinson, J. D., Workneh, D. A., and Morris, G. J.: A technique for quantifying heterogeneous ice nucleation in microlitre supercooled water droplets, Atmos. Meas. Tech., 8, 2437-2447, https://doi.org/10.5194/amt-8-2437-2015, 2015.
Wheeler, M. J., Mason, R. H., Steunenberg, K., Wagstaff, M., Chou, C., and Bertram, A. K.: Immersion freezing of supermicron mineral dust particles: Freezing results, testing different schemes for describing ice nucleation, and ice nucleation active site densities, J. Phys. Chem. A, 119, 4358-4372, https://doi.org/10.1021/jp507875q, 2015.

Wilson, T. W., Ladino, L. A., Alpert, P. A., Breckels, M. N., Brooks, I. M., Browse, J., Burrows, S. M., Carslaw, K. S., Huffman, J. A., Judd, C., Kilthau, W. P., Mason, R. H., McFiggans, G., Miller, L. A., Nájera, J. J., Polishchuk, E., Rae, S., Schiller, C. L., Si, M., Temprado, J. V., Whale, T. F., Wong, J. P. S., Wurl, O., Yakobi-Hancock, J. D., Abbatt, J. P. D., Aller, J. Y., Bertram, A. K., Knopf, D. A., and Murray, B. J.: A marine biogenic source of atmospheric ice-nucleating particles, Nature, 525, 234-238, https://doi.org/10.1038/nature14986, 2015.

Wurl, O., Miller, L., Röttgers, R., and Vagle, S.: The distribution and fate of surface-active substances in the seasurface microlayer and water column, Mar. Chem., 115, 1-9, https://doi.org/10.1016/j.marchem.2009.04.007, 2009.

Wurl, O., Wurl, E., Miller, L., Johnson, K., and Vagle, S.: Formation and global distribution of sea-surface microlayers, Biogeosciences, 8, 121-135, https://doi.org/10.5194/bg-8-1212011, 2011.

Yun, Y. and Penner, J. E.: An evaluation of the potential radiative forcing and climatic impact of marine organic aerosols as heterogeneous ice nuclei, Geophys. Res. Lett., 40, 4121-4126, https://doi.org/10.1002/grl.50794, 2013.

Zhang, Z., Liu, L., Liu, C., and Cai, W.: Studies on the sea surface microlayer: II. The layer of sudden change of physical and chemical properties, J. Colloid Interf. Sci., 264, 148-159, https://doi.org/10.1016/S0021-9797(03)00390-4, 2003.

Zobrist, B., Marcolli, C., Peter, T., and Koop, T.: Heterogeneous ice nucleation in aqueous solutions: the role of water activity, J. Phys. Chem. A, 112, 3965-3975, https://doi.org/10.1021/jp7112208, 2008. 